\title{
Economic Violence, Sexual Exploitation and Psychological Trauma: A Comparative Study of The Predicament of Women in Gloria Naylor's The Women of Brewster Place and Mariama Ba's So Long a Letter
}

Diome Faye*

Laboratoire d'Etudes et de Recherches Anglophones, Cheikh Anta DIOP University, Dakar, Senegal

DOI: 10.36348/JAEP.2019.v03i09.005 $\quad$ | Received: 21.09.2019| Accepted: 28.09.2019| Published: 30.09 .2019

*Corresponding author: Diome Faye

\section{Abstract}

Gloria Naylor, in the Women of Brewster Place: A Novel in Seven Stories depicts the economic, sexual and psychological conditions that African American women go through. The female characters of the novel are victims of economic and sexual pressures that bring about psychological trauma. For Mariama Ba, in So Long A Letter, she points out the traditional practices and deep- seated customs that impact on the economic, sexual and psychological well-being of Senegalese women. Women's lacks of moral comfort, the emotional intensity and the psychological shocked caused by men's betrayal are the results of a misinterpretation, misconception and misunderstanding of tradition, customs and religion. The main purpose of the paper is to show how, Gloria Naylor and Mariama Ba, from different angles and cultures, has faithfully depicted the economic, sexual and psychological predicaments that Senegalese and African American women are suffering.

Keywords: Women, oppression, economic, sexual, psychological, society, tradition, gender, racism, customs.

Copyright @ 2019: This is an open-access article distributed under the terms of the Creative Commons Attribution license which permits unrestricted use, distribution, and reproduction in any medium for non-commercial use (NonCommercial, or CC-BY-NC) provided the original author and sources are credited.

\section{INTRODUCTION}

A careful reading of African American female writers' works reveals that oppression is in the majority of cases experienced through consideration linked to gender and racism, whereas in African literature, women oppression is caused by tradition and customs. Even if there are big differences in terms of social background, geographical areas and cultural context, the two novels have so many similarities among which the theme of women's oppression. And it is a theme dear to both novelists who set out deliberately to help rectify this situation or this injustice, by writing fiction that brought about women to the foreground.

Gloria Naylor is a native New Yorker who was born in 1950. She is a distinguished novelist best known for representing the experiences and views of black women. The Woman of Brewster place, published in1982, points out the lives of seven different black women who live in a dead-end street, Brewster Place.

Mariama Ba's novel, So Long A Letter published in 1979, is set in a society, where tradition and customs are still deep seated. Written in the form of a letter, Mariama Ba's novel denounces women's plight in order to draw people's attention on their suffering under the yoke of tradition and customs. The objective of our study is to deal with women's oppression in their respective societies by laying the stress on the different types of oppression among which the economic violence, sexual exploitation and psychological trauma.

\section{ECONOMIC VIOLENCE}

As a state, oppression can be considered as the consequence of deprivation, exclusion, discrimination and exploitation. In other words, it is a consistent denial of essential resources. In the economic field, oppression always involves violence either direct or indirect. When it is indirect, it means severe material deprivation, such as controlling the economy and paying only subsistence wages.

In the United States, many blacks cannot believe that America is a country where people have the same equal opportunities. In fact, almost all African Americans are affected by poverty. It seems as if that poverty was only what fate has in store for them. The problem to find and keep a well paid job is the main cause of the deep rooted economic predicament African Americans have been experiencing in the United States. In $\underline{\text { The Debt }}$, Randall Robinson notifies: 
High infant mortality. Low income.

High unemployment. Substandard education. Capital incapacity. Insurmountable credit barriers. High morbidity. Below average life span. Over representation in prison and on death row. Each a cause and or a consequence of a disabling poverty (of means and spirit) that has shackled all too many entire black family trees since the Emancipation Proclamation; as if the painful fates had been painted onto some antebellum canvas that had dried means during slavery [1].

Indeed, the economic ostracizing of the black man and the harrowing discrimination in the unemployment framework make the African Americans a quasi- poor community. A great number of black people in the United States of America depends on the welfare department. The economic system has replaced race as the determinant of individual opportunity for African Americans. Derisory or absent incomes for many blacks is the main issue of black people's social life. This has created many frustrations among the black community, has repercussions on the management of their own family and gives birth to what is called the matriarchal poor family.

Brewster Place epitomizes the failure of the African American community and the economic deadlock in which its members are trying to evolve harshly. These members are undergoing the adverse effects of the power of money on the penniless one. And as William Dubois puts it in his book entitled The Soul of Black Folk: "To be a poor man is hard, but to be poor in a land of dollars in the very bottom of hardships" [2] In addition, the equal rights and opportunities are only in theory but not in practice.

The poverty of the single black mother is very hard. It is very difficult, indeed even nearly impossible for a black woman to earn her living honestly and decently. The lack of education and early pregnancy cause black women to be more vulnerable and exposed to the effects of poverty. For instance, in The Women of Brewster Place, Mattie Michael lives like single mothers and experiences the same poverty and difficulty as they do. Her wage is too low, in so much so that she cannot save money. Her derisory salary cannot pay her the luxury of saving money and satisfying her needs and her baby's. Gloria Naylor points out the economic hardships she is faced with as follows:

Mattie could not seem to save enough money to move. The baby sitter cost her almost half of her weekly salary and after she paid a week's rent and bought food, there was just enough left over for carfare. She stopped going to the movies on Saturday and only bought clothes or shoes when she had reached the state where she was ashamed of being seen in the street [3].

The level of poverty in a matriarchal family is very harrowing. The father's absence increases the number of charges the mother has to support. Most of the time, she cannot succeed in both giving a good education and feeding the children. For example, Cora Lee has no job and she depends entirely on the welfare services to nurture her six children. She cannot have the situation under control and has no attention to her children who are underfed. Some of them probe in the garbage can to find food. Kiswana Brown tries to explain her how she has found Sammy eating from the dustbin. She says: "He was downstairs eating out of one of the garbage cans and I thought you oughta know because, well, he might be hungry or something [4].

Children raised in poor families have less access to material resources such as food, shelter and health care. According to Svetlana Yampolskaya, in the journal of Emotional and Behavioral Disorders: "Teenage parents have represented the majority of welfare recipients and have consumed the majority of welfare benefits" [5]

Actually, one can realize that Cora Lee is one of them. Indeed, as astonishing as it may appear, the episode of the child trying to find food in the dustbin is the indication of a very rooted poverty that is too difficult or even deprived of food in so much so that the individual is obliged to look for it in dirty places is the lowest step of poverty. When one is looking for food, he or she aims at surfeiting himself or herself but not endangering his or her life by eating filthy things. Cora Lee and her many children make people see the concern about the increasing numbers of new born infants very often created by ephemeral unions. These children born from clandestine intercourses must survive on welfare or the kindness of relatives or even strangers as Mattie Michael or Kiswana Brown do with Cora Lee's children. Too many African Americans create babies and then do not take the responsibility to take in charge of them. As a result, many black children are growing up in fatherless houses and live in dependency and poverty.

In addition, in The Women of Brewster Place, Eugene, in Ciel's section is alienated by unemployment and many disillusions from life expectancy. Like any African American husband who, plagued with the defect, he develops a despicable image of a husband. He begins to threaten the quietness of his own family, going so far as to disturb his own child's sleep by 
turning up the stereo sound very loud. The repressed feeling of his situation as a marginal and discriminated man finds its outlet in the family circle and especially in his wife Louise Lucielia Turner. The latter has seriously experienced the economic oppression that the American society has inflicted upon African American men. Eugene finds the family circle a place in which he can exercise his power without any restriction. From this point of view, one can say that the economic deadlock Ciel goes through with her child Serena is the result of the grudging poverty both African American men and women are confronted in their daily lives. This economic situation is the root cause of the restless life Ciel lives in her household.

The violent dispute between Eugene and Ciel about his departure for an alleged job to one knows where, indirectly causes their daughter's death. Serene was momentarily abandoned by her parents who were busy quarrelling. In the meantime, she set to chasing a roach, which led her to insert a fork into an electric socket. She died from electrocution while her parents had been quarrelling.

In sum, one can say vigorously that this sad story is due to the bad economic situation women encounter in their households. Eugene appears to be nothing but the product of violence generated by a wicked capitalistic system. His lack of job pesters him and remains a sufficient motive for him to leave his wife and daughter without heartbreak or remorse. Gloria Naylor gives a description of such a pathetic scene in the following paragraph:

\section{His eyes were flashing with the anger of a caged animal. He slammed down the top of the suitcase and yanked it off the bed. "Look, Ciel, believe whatever the fuck you want. I gotta go”. He tied to push past her [6].}

For him, that little family constitutes a heavy burden he cannot bear for the rest of his life knowing that his situation will never move further than a small step, that is to say his life cannot be improved. Being a woman, it is clear that Ciel will mostly suffer from the harsh poverty which affects Eugene's family.

The economic oppression women are confronted with in The Women of Brewster Place stems from two sides. On the one hand, African American men do not like women stay at home and face with the hard living conditions of their daily lives. They shrink from their responsibilities as partners and run away from the household. On the other hand, women's plight can be justified by the American society which does give black men the require means to take care correctly of their families.
As matter of fact, the economic oppression Mariama Ba depicted in So Long a Letter is nearly the same in terms of disadvantages even if one can note a remarkable difference in the way they have dealt with the issue.

In So Long a Letter, the economic oppression may be analyzed from two different angles. The first one is that women undergo in their polygamous lives because of the relinquishment of men, and the second one derives from some customs which, in the way they are practiced in society, turn out to be very oppressive on people economically speaking.

Abandoned by Modou to the detriment of the second wife, Binetou, Ramatoulaye seems to be tossed between two extremes. She becomes the head of the family and must from then on bear the responsibility or the burden to both solely feed and take care of the children. And it is well- known that in cities where Ramatoulaye lives, even if she is a school teacher, facing the day-to-day demands of childbearing is a heavy state of responsibility financially point of view. Life in cities is too expensive because of the high cost of living. Food, education, transport and housing are the most pressing problems heads of families are confronted with in their daily lives. In the field of education, her children's financial situation is revealed by Daba's advice to her brothers and sisters "Above all, don't let mum know that it is stifling in those buses during the rush hours" [7]. The protagonist in So Long a Letter is not an exception from this rule. She explains that:

The purchase of basic foodstuffs
kept me occupied at the end of every
month. I made sure that I was never
short of tomatoes or of oil, Potatoes
or onions during those periods when
they became rare in the market; I
store bags of rice "Siam rice",
much loved by Senegalese. My brain
was taxed by new financial
gymnastics [8]

A close examination of the quotation above obviously proves that she lives under the yoke of economic oppression. She sheds light on her economic plight through these words "I was left with empty hands "[9].This current situation she encounters can go along with that of Helene Wright in Sula_by Toni Morrison. Helene Wright nurtures and educates her daughter without any help from her husband who is often absent. When her man has deserted, Nel also does her uttermost best to find a job in order to provide her small family with the necessary. This is indicated as follows:

There was no more fifty dollars in brown envelops to count on ;(...) She got a better job working as a chambermaid in the same hotel Jude 
had worked in. The tip was only

fair, but the hours were good, she

was home when the children got out

of school [10]

From these views, one can say that women, both in African and in the African American community are under an economic oppression due to their husbands' absence or abandonment. They play now the role of the householder and breadwinner.

In the societies where polygamy is implemented, women economic plight generally speaking originates from the various social iniquities they experience during their polygamous life. They are most of the time subjected to discrimination, segregation and favoritism in their households and this in all sectors of life. Financially point of view, women do not share the same privileges or advantages of their husbands. And it is this favoritism which makes the economic situation of Ramatoulaye more unbearable. The moment she has faced with the problems of financial means to take care correctly of her twelve children has corresponded with the period Binetou, the second wife, has been living an opulent life. She has started wearing very expensive off- the leg dresses, and she explains to Daba that she has a sugar- daddy who pays for them. This metamorphosis of Binetou appears in mother-in-law who is showing off during the ceremonies the wealthy situation in which Modou has put her. That golden age of their lives coincides with the grave doubt of Ramatoulaye concerning the heavy responsibility which weights on her shoulders. She asks herself: "Did I have enough energy to bear alone the weight of responsibility, which was both moral and material?'[11]

This statement reflects the profound financial uncertainties Ramatoulaye is going through in her house.

In So Long a Letter, the economic oppression has gone beyond the individual in order to land on the whole community. The way Mariama Ba has depicted the ceremony of the third day sheds light on the selfimposed economic oppression the Senegalese society inflicts upon itself. A fair analysis of this ceremony shows that the heavy burden certain customs put on the community turns out to be oppressive if it is minutely examined in the economic field.

Living in a poor country, Senegalese people spend money lavishly like water during these ceremonies in order to show off their position in society or their wealth. Mariama Ba criticizes this practice by making a comparison between the traditional and the modern way it is done. She says:

In former times, this was made in kind: millet, livestock, rice, flour, oil, sugar, milk. Today it is made conspicuously in bank notes, and no one wants to give less than the other. A disturbing display of inner feeling that cannot be evaluated now measured in francs [12].

The competitions that have recently existed the ceremonies are part and parcel of the economic violence people are going through in their daily lives. People's friendships and love are now measured by the amount of bank notes given during the festivities.

\section{SEXUAL EXPLOITATION AND THE PSYCHOLOGICAL BURDEN}

In the United States, the relationships between blacks and whites, slaves and masters have always been a very much debated issue. Being the dominant class in all fields, white people use all the means they have at their disposal in order to oppress the black community socially, economically and sexually. From the sexual point of view, their economic success is the tool they use to exploit black people.

Gloria Naylor, in The Woman of Brewster Place, vehemently denounces that sexual exploitation her African-American sisters are experiencing in their daily lives. Ben's daughter, Lame, cannot do farm work like her parents. For this reason, she is hired to a white man, Mr. Clyde, who is the owner of the land rented by her parents. Ben's question to his wife Elvira, "why she (the daughter) goes to spend the night there?" is relevant enough to prove, as the girl confirms later, that their daughter is subjected to the sexual whims of her employer.

However, we think it is interesting to underline the presence of a certain form of racism referred to by Gloria Yamato as "unaware self-righteous racism". That is to say, the form in which the white man assigned himself as "the good white man" as opposed to the "bad whites". In response to Elvira, the daughter's mother who tells him, "we sure appreciate the extra land you done rented us". Mr. Clyde expresses his happiness to make all his tenants in best conditions.

In other words, this form of racism just uses the well known paternalistic way by which a master shows deceitful kindness to his subjects. This practice is very dangerous in the sense that it always aimed at perpetuating domination and offers no possibility of revolt. Even today, many people, individual or as group are still falling into this trap. This sexual oppression Ben's daughter goes through in the United States really exists in Africa. Buchi Emecheta, in The_Slave Girl, portrays the extent to which sex is a way of oppressing women by giving them less value. In the book, the behavior of Pa Palagada and his son Clifford towards the slave girl as the perverse union between $\mathrm{Ma}$ 
Palagada and the white Portuguese prove the sexual exploitation women are victim of in this male centered community. This point of view is shared by Fatou Diouf Kandji when she sustains the idea that:

The sexual revolution benefits men only. It is a male oriented and antiwoman in so far as women cannot compete with men in license and promiscuity. Women will always be the losers. The sexual revolution makes women more vulnerable as it turns them into sex objects and easily available common properties [13].

In addition to the sexual exploitation of Ben's daughter, Etta Mae Johnson is described as an exploited character who occupies the second place of mistress for Simeon. She is not the legitimate wife but only the easy girl who can help to soothe the weakness of the flesh, and with whom one can spend a very nice time without any commitment. In fact, Simeon one of her suitors wants her anytime at his mercy and is not ready to give her plane fare to Brewster Place. She appears to be the sex matter itself and is not considered as a human being. This consideration finds a better illustration and depiction in her encounter with Reverend Moreland $\mathrm{T}$ Woods. Indeed,

Moreland was captivated by the beautiful woman at his side, her brown flesh and bright eye carried the essence of nectar from some untamed exotic flower and the fragrance was causing a pleasant disturbance at the pit of his stomach [14].

Furthermore, Moreland is not ready to treat Etta seriously and goes so far as to abuse her. He considers her as a plaything, spends good time with her, leaves her alone and deeply disappointed her at a corner of the street.

The treatment of Etta Mae Johnson as a plaything for Reverend Moreland T Woods is similar to that of Cora Lee who is regarded as a sexual outlet for many black men. Cora Lee can be seen as a sexual object where black men often drown their sorrows. For argument's sake, she has six children and only Maybelline and Sammy have got the same father. Men abuse her and leave her after having babies with her. For instance, Brucie's father really disappoints her simply because he had promised to marry her and take care of welfare but on purpose, he went out for a carton of milk and never came back.

Moreover, it is worth mentioning that poverty in the United States is one of the causes of the sexual oppression women are victim of. As far as Lucielia is concerned, her husband Eugene is alienated by unemployment and many disillusions from life expectancy. Like any African-American husband who, plagued with this defect, he develops a despicable image of her husband. Eugene not only comes to the house at night to have sexual intercourses with Lucielia, but he also he begins to threaten the quietness of his own family, going so far as to disturb his own child sleep by turning up the stereo sound very loud. The repressed feeling of his situation as a marginal and discriminated man finds its outlet in the family circle, a place in which he can exercise his power without any restriction.

Contrary to Gloria Naylor, Mariama Bâ depicts sexual oppression through the possibility men have to inherit the brothers' wives named levirate marriage. In fact, the origin of that practice can be set as far back as the time of the Hebrew prophet Moses. That practice which was known as levirate marriage was a law imposed by Moses which urged a man to marry the childless widow of his deceased brother. It was a way of safeguarding the alliance between the families of which the husbands were the representatives.

But in many African societies, we notice a misrepresentation of that practice because it is used in such a way that the wife is regarded as part of the commodities involved in the heritance. Therefore, the levirate marriage as practiced in African societies is different from the original meaning on the one hand but also from the religion stance on the other hand. In fact, the religious standpoint, particularly Islamic religion, allows the woman to accept or not the levirate marriage. Her opinion is a sine qua none condition for the union which should not be imposed upon her.

In So Long a Letter, Mariama Ba uses that practice as a device in order to show the extent to which women are used and abused by men. Tamsir, Modou Fall brother's behavior is only based on sexual instincts than a mission to fulfill. His reaction urges us to say that he is motivated to satisfy a former sexual desire since at the beginning of the announcement of the possibility of a marriage between him and Ramatoulaye; he regards her as his luck. He says that he prefers her than the other; one meaning Binetou.

Mariama Bâ uses the voice of the protagonist to criticize that sexual oppression women are confronted with even when they are mourning their former husbands. She puts it as follows:

What a declaration of love, full of conceit, in a house still mourning. Already you want to build a new for yourself, over a body that is still warm. While we are praying for Modou, you are thinking of future wedding festivities [15]. 
Diome Faye; J Adv Educ Philos, Sep 2019; 3(9): 335-341

Karl Marx backs up the idea that alienation is the enslavement of the human being due to political, social and economic obstacles. He goes further by stating that this enslavement leads to the lost of the sense of the self, of your faculties and liberties. From this statement, one can without hesitating put straight away some characters of The Woman of Brewster Place and So Long a_Letter in the same vein.

In $\mathrm{Ba}$ 's novel, the degrading and conflicting relationships combined with the arrogance of the hostile environment torment Jacqueline's psychological state of mind. From then on, Jacqueline an Ivorian woman who gets married with a Senegalese Samba Diack has experienced the side effects of betrayal. Jacqueline seems here to be caught between two extremes. On the one hand, she is rejected both by her husband's family and society, and on the other hand Samba turns his back to fetch pleasure in other women.

The Senegalese society and Samba Diack's family reject Jacqueline by making her go through the feeling of non-belonging. This rejection is visible in the sense that they refuse to call Jacqueline by her real name and nickname her "gnac". This kind of appellation is shocking because most of the time it underestimates people's egos. The rejection through nickname or appellation reminds us of that of AfricanAmericans when they were brought in the United States. Blacks have been identified under many names in America. Among those we can quote "from nigger to Negro, negro-black, black-afro American, afro American to African-American". These nicknames were the means used by white people to show there brothers that you do not belong. To go back to Jacqueline, we can say that she is a stranger in her own house simply because neither the Senegalese society nor her family-in-law does warmly welcome her. This rejection is all the more threatening psychologically speaking as it urges the individual to put into question his or her nature as a human being.

Concerning Samba Diack, his betrayal is indeed bitter for, it is the break-up of an agreement on which they have already made. This situation undoubtedly echoes on Jacqueline's psychology. She ends up in a loss of mental balance which leads her to Fann hospital. The lack of moral comfort, the emotional intensity, the psychological suffering caused by the ungratefulness and the betrayal she is confronted with, dramatically undermines her psychological frame of mind. Her situation is nearly similar to that of Antoinette in Wide_Sargasso Sea by Jean Rhys. In that book, Antoinette is victim of despair and abandonment because her own mother, Annette is depicted as a foreigner from Martinique, which exposes her to the violence and hatred, particularly when she is persecuted by a mob of islanders.
Jacqueline's loneliness due to the unfaithfulness of Samba Diack, put together with her second thoughts for having disobeyed her protestant parents who were against her marriage can be put among the root causes of her mental illness. Jacqueline complained of a disturbing lump in her chest under the left breast. She said she had the impression that a sharp point had pierced her there and was cutting through her flesh right to her very bones. This painful situation has only one cause, her husband who stands here for the oppressor of Jacqueline. The doctor highlights it by explaining her in these terms:

Madame Diack, I assure you that there is nothing at all wrong with your head. The $x$-rays have shown nothing and neither have the blood tests. The problem is that you are depressed, that is...not happy. You wish the conditions of life were different from what they are in reality. And this is torturing you [16].

If Jacqueline escapes from death in So Long a Letter $_{2}$ Mireille in The Scarlet Song unfortunately ends up dying due to the same situation Jacqueline has experienced. Apart from Jacqueline's psychological oppression an examination of Ramatoulaye's actions and speeches reveal that she is in a grave doubt concerning her possibility to bearing the heavy responsibility she has to carry out after the abandonment of her husband. And this stage of life she is faced with really puzzles her mind. She asks herself: "Did they have enough energy to bear alone the weight of responsibility which was both moral and material" [17].

This statement or question reflects that Ramatoulaye's conscience is not at ease. She is morally suffering because she is aware of the importance of the presence of the father in the education and the psychological development of the child. She says "Boys cannot succeed without their father" [18]. Bâ's work creates mono-parental families which are very often broken up and where children live with a divorced or widow. And as it is known, the presence of the father is essential to the moral and psychological balance of children. It creates on the child a strong superego. This superego unable the child to control itself and be in a position to weigh the pros and cons before it undertakes any actions. It also permits the child to have a sense of responsibility and lessen his selfishness.

Man is a human being composed of body and mind. The two are closely connected and all the pains that hurt the body are psychologically felt. In other words, physical wreckages echo on our psychology. From that point of view, one can say that the physical hardships some women characters have experienced in 
The Women of Brewster Place have affected at the same time their minds.

Mattie goes through physical pain when she left her dilapidated room for the quest of another comfortable one. She has spent a whole night walking with Basil without sleeping. Wandering without a precise destination, she feels pain both in the physical and psychological level. This suffering is pointed out as follows: "She was so tired that she could not think, and her legs were starting to tremble from lack of sleep and the heavy load she had carried around all day [19]."

In The Women of Brewster Place, apart from society, husbands, lovers, sons shower moral pain on their mothers. Trapped in the physical, psychological, and repressive environment of the prison cell, for having killed a man in the bar, Basil's sufferings have brought about psychological disorder in her mother's state of mind. The execrable conditions of Basil awaken Mattie's compassion for him and resentment for his condition. Mattie is all the more frightened and tormented as Basil threatens to kill himself if ever he has to go back to prison after the hearing. Deeply worried by the menace, Mattie sells her house to stand bail for her son. All this prove that Mattie is psychologically disturbed by the situation of her cherished son.

If psychology is to be defined as the study or science of the mind and the ways it works and influences behavior, we can declare that Louise has gone through psychological sufferings in two different levels: Firstly, the death of her beloved daughter Serena, and secondly the indifference of Eugene when she was in deep mourning for her daughter. In fact, the death of Serena has repercussions on Louise's mind because death, as an ultimate existential dilemma arouses terrible anxiety as it offers an avenue towards authentic self discovery.

\section{CONCLUSION}

If Mariama Ba shows right at the beginning of her novel the importance of solidarity, Gloria Naylor's novel forces its readers to confront the sordid and oppressive social environment in which they have always lived. The vast majority of Naylor's figures live like the humanity T.S.Eliot portrays in his poem the Hollow Men: without a guiding vision or faith, they lead their futile existence, like zombies, in the midst of a cultural and spiritual wasteland which also fills them with boredom, suffering and unhappiness.

\section{REFERENCES}

1. Bederman, G. (1995). Manliness and Civilization. Chicago, IL: University of Chicago Press.

2. Chow, E. N. L., Wilkinson, D. Y., \& Zinn, M. B. (1996). Race, class, \& gender: common bonds, different voices. Sage Publications, Inc.

3. Collins, Patricia Hill. (1990). Black Feminist Thought. NY: Harper Collins.

4. Connell, R. W. (1987). Gender and Power. Stanford, CA: Stanford University Press of Minnesota Press.

5. Cott, N. F. (1987). The grounding of modern feminism. Yale University Press.

6. D'Emilio, J., \& Estelle, F. (1988). Intimate Matters: A History of Sexuality in America. New York: Harper and Row.

7. Diouf-Kandji, F. (1997). Female Sexuality in Buchi Emecheta's Writings in Bridges, An African Journal of English Studies, 23(4), 655-664.

8. Dubois, E. C. (1978). Feminism and Suffrage. Ithaca, NY: Cornell University Press.

9. Gordon, A. D. ed. (1997). Selected Papers of Elizabeth Cady Stanton and Susan B. Anthony. New Brunswick, NJ: Rutgers University Press.

10. Gordon, L. (1990). Woman's Body, Woman's Right: Birth Control in America. Revised edition.

11. Griffith, E. (1984). In Her Own Right: The Life of Elizabeth Cady Stanton. New York: Oxford University Press. 